\title{
Od Otniela do Saula. Początki państwowości izraelskiej
}

Historia Izraela w Kanaanie rozpoczyna się wraz ze śmiercią Jozuego. Źródła biblijne ukazują zaistniałą sytuację jako czas wielkiej próby: Izraelici stanęli twarzą w twarz z innymi ludami zamieszkującymi Kanaan. Wybuchały liczne wojny, z których Naród Wybrany nie zawsze wychodził zwycięsko. Brak było jednolitego przywództwa, a poszczególne plemiona musiały oddzielnie walczyć o swoje przetrwanie. Sytuacja pogorszyła się jeszcze, gdy do walki z Izraelitami stanęli świetnie uzbrojeni i zorganizowani Filistyni. Dopiero z czasem pojawiali się, przejmując władzę, lokalni przywódcy stający na czele plemiennych konfederacji; był to czas sędziów i początków budowania monarchii.

Był to równocześnie okres, w którym zaczęła się kształtować pewna więź łącząca luźne wspólnoty, przekształcając je stopniowo w naród o w miarę jednolitej kulturze i religii. Był to proces długotrwały i pełen trudności, a nawet bratobójczych walk. Postaciami, które miały wówczas decydujące znaczenie, byli właśnie sędziowie wybierani przez Jahwe i stający na czele narodu w tych trudnych momentach. Byli oni bezpośrednimi poprzednikami królów, którzy zbudowali zjednoczone państwo; zapoczątkowali złoty okres w dziejach Izraela, który jest wspominany przez Żydów do dzisiaj.

Czytając księgi historyczne Starego Testamentu należy sobie oczywiście zdawać sprawę, że przedstawiany tam obraz jest tylko wersją jakichś wcześniejszych informacji. Wersją mniej lub bardziej wyidealizowaną. Ciągle toczą się spory na temat ich wiarygodności. Próbuje się znaleźć w tekście elementy, które można uznać za odzwierciedlające rzeczywiste wydarzenia z wczesnego okresu w dziejach Izraela, oddzielając je od tych, które są tylko wizją autorów późniejszych, tworzących swoje dzieło z teologicznego punktu widzenia ${ }^{1}$.

${ }^{1}$ Nieuzasadniony wydaje się nadmierny krytycyzm prowadzący do odrzucenia historyczności wczesnego okresu w dziejach Izraela łącznie ze Zjednoczoną Monarchią, jak czyni to P. R. DAvies (In Search of „Ancient Israel”, Sheffield 1999 [Journal for the Study of the Old Testament. Supplement Series, 148]); jak pisze L. L. Grabbe (Are Historians of Ancient Palestine Fellow Creatures - or Different Animals, [w:] Can a „History of Israel” Be Written, ed. by L. L. Grabbe, Sheffield 1997, s. 24-34 [Journal for the Study of the Old Testament. 
Pomocne są tutaj informacje pochodzenia pozabiblijnego, które jednak mogą być używane tylko jako materiał pomocniczy, uwiarygodniający przekazy biblijne.

Niniejszy artykuł jest próbą zbadania dziejów Izraela w okresie sędziów oraz czynników, które wpływały na zjednoczenie i powstanie jednego narodu w miejsce kilkunastu luźnych wspólnot plemiennych. Interesujące jest także prześledzenie pewnej ciągłości władzy pomiędzy sędziami a królami, którzy później zajęli ich miejsce. Jak się wydaje, takim czynnikiem mogły być funkcje kapłańskie.

\section{Okres sędziów}

Sytuację Izraela Księga Sędziów streszcza krótko: „W owym czasie nie było króla w Izraelu i każdy czynił to, co mu się podobało" (Sdz 17, 6; 18, 1; 19, 1;21, 25). Można to rozumieć w ten sposób, że prawo i porządek, jaki znano w późniejszym okresie, jeszcze nie istniał². Był to trudny okres w dziejach powstającego narodu, pełen walk z wrogami i konfliktów wewnętrznych. Jego początek szacunkowo datuje się na koniec XIII wieku przed Chr. ${ }^{3}$ Badań nad tym okresem nie ułatwia sama Księga Sędziów, która ukazuje przebieg wypadków według określonego, teologicznego schematu:

- Izraelici odwracają się od Jahwe i służą Baalowi;

- czyniąc w ten sposób, ściągają na siebie gniew swego Boga, który powoduje, że Izrael uciskany jest przez wrogów;

- powołany zostaje sędzia, który wyzwala naród;

- następuje okres spokoju przed kolejnym odstępstwem od Jahwe4.

Etymologia. Powstaje pytanie, kim byli owi tajemniczy „sędziowie” i jakie były ich funkcje we wspólnocie? Hebrajskie šôpett, które tłumaczone jest jako „sędzia”, pochodzi od rdzenia špt oznaczającego „rządzić, zarządzać” i obejmuje także funkcję podejmowania decyzji oraz sprawowania sądów. W kręgu kultury zachodniosemickiej określenie to było często stosowane do władców i namiestników, np. w Ugarit bóg Baal określany jest jako

Supplement Series, 245]): „Używamy tekstów biblijnych, ponieważ je mamy i nie mamy wielu źródeł, które moglibyśmy preferować”, ale „nawet całkiem legendarne przekazy mogą zawierać pewnego rodzaju historyczny rdzeń".

${ }^{2}$ G. W. Ahtström, The History of Ancient Palestine from the Palaeolithic Period to the Alexander's Conquest, Sheffield 1993, s. 377 (Journal for the Study of the Old Testament. Supplement Series, 146). J. S. SynowIEC (Izrael opowiada swoje dzieje, Kraków 1998, s. 111) uważa, że zwrot ten podkreśla wolność Izraelitów, których nie można było zmusić do prac przymusowych.

${ }^{3}$ S. M. WARner (The Dating of the Period of the Judges, VT 28 [1978], s. 463) jako przybliżoną datę początków działalności sędziów podaje rok 1373 przed Chr.

${ }^{4}$ J. A. Callaway, Osiedlenie się wziemi Kanaan, [w:] Starożytny Izrael: od czasów Abrahama do zburzenia Jerozolimy przez Rzymian, przeł. W. Chrostowski, Warszawa 1994, s. 131-132. 
tpt (sędzia) i mlk (król) m.in. w KTU 1, 23. 43-445. W inskrypcjach punickich i neopunickich $\check{s} p t$ odpowiada tytułowi suffètes tłumaczonemu przez Rzymian jako iudex oznaczający konsula; później, kiedy otrzymał władzę nie tylko wojskową, ale i cywilną, znano go jako rex ${ }^{6}$. W innych tekstach biblijnych (Iz 16, 5; Ha 7, 7; Am 2, 3) šôpēt wyraźnie już oznacza władcę; podobnie jest z wyrażeniem „sędziowie ziemi” w Ps 2, 10; 148, 11; Iz 40, $23^{7}$.

Wielu informacji dostarcza także literatura akadyjska, gdzie rdzeń špt pojawia się stosunkowo często. W języku akadyjskim istnieją dwa homonimiczne rdzenie: $\check{s} p t \underline{\text { I }}$ oraz špt II. Pierwszy z nich używany był często $\mathrm{w}$ połączeniu $\mathrm{z} d y n$, kiedy pojawiał się $\mathrm{w}$ związku z zagadnieniami prawnymi. Z kolei špt II oznacza „grozič” lub „ostrzegać”. Charakterystyczne jest, że w znaczeniu „groźby” lub „ostrzeżenia” špt pojawia się tylko w okresie starobabilońskim, co poświadczają teksty z Mari. Rzeczownik šāpițum (sędzia) nie jest poświadczony aż do okresu po upadku państwa starobabilońskiego (ok. 2000-1600 przed Chr.). Świadczyć to może o tym, że šāpițum jest pochodzenia zachodniosemickiego, a do języka akadyjskiego trafił za pośrednictwem Amorytów. Przed ich przybyciem tytułem „sędziego” był dayyānu(m) (urzędnik), który rozstrzygał konkretne sprawy (podobnie jak współczesny sędzia). Założenie to znajduje poparcie w fakcie, że rdzeń $d y n$ używany jest równolegle we wszystkich językach semickich. Podczas gdy dayyānu $(m)$ zajmował się tylko przypadkami, z którymi strony zwróciły się do niego, šäpițum sprawował także wiele innych funkcji, które obejmowały m.in. rozstrzyganie spraw znajdujących się pod jego jurysdykcją ${ }^{8}$.

Teksty z Mari świadczą o tym, że sprawować sądy oraz rządzić mogła ta sama osoba - był to właśnie šāpițum. Był on również wyznaczany do zarządzania określonym terytorium w czasie nieobecności šarrum (władcy). Sprawował komendę wojskową w czasie kampanii wojennych (ARM 1, 73: 45-53). Z powodu swojej uprzywilejowanej pozycji w społeczeństwie šāpițum rozsądzał również codzienne, domowe spory $(A R M 8,84: 1-11)^{9}$. W litera-

${ }^{5}$ C. F. Fensham, The Ugaritic Root Tpt, JNES 43 (1984), s. 63-69.

${ }^{6}$ T. IsHIDA, The Leaders of the Tribal Leagues "Israel" in the Pre-Monarchic Period, RB 80 (1973), s. 515-518.

7 J. DAY, The Canaanite Inheritance of the Israelite Monarchy, [w:] King and Messiah in Israel and the Ancient Near East, pod ed. by J. Day, Sheffield 1998, s. 72 (Journal for the Study of the Old Testament. Supplement Series, 270).

${ }^{8}$ T. L. J. MAFICO, Judge, Judging, [w:] ABD, pod red. D. N. Freedmana, New York 1997 (CDR). Na liczne podobieństwa instytucji starobabilońskich i wczesnego Izraela zwraca także uwagę A. Malamat, Mari and the Bible: Some Patterns of the Tribal Organization and Institutions, JAOS 82 (1962), s. 143-150; patrz także tenże, Pre-monarchical Social Institutions in Israel in the Light of Mari, [w:] Congress Volume, Jerusalem 1986, Leiden (E. J. Brill) 1988, s. 165-176 (SVT 40).

9 A. Marzal, The Provincial Governor at Mari: His Title and Appoitment, JNES 30 (1971), s. 186-217. 
turze ugaryckiej Dan'il jako król był zobowiązany do sprawowania sądów i wymierzania sprawiedliwości w obronie potrzebujących (wdów, sierot, przybyszy - KTU 1, 17. 6-8; 1, 16. 45-54). Także Stary Testament ukazuje, że przedmonarchiczni władcy ( ŝp $\left.^{e} t \hat{\imath} i m\right)$ prowadzili wyprawy wojenne (Sdz 2, 16; $3,10)$, rządzili państwem $(10,3 ; 12,7)$ oraz wymierzali sprawiedliwość (4, 4). Rozważania powyższe wskazują, że rdzeń špt ma różnorodne znaczenie zarówno w języku akadyjskim, jak i w Starym Testamencie. Aby określić, co wyraża, najlepiej zwracać uwagę na kontekst, w którym ów špt się pojawia ${ }^{10}$.

Rola šôpēt w Starym Testamencie. Rzeczownik šôpet używany jest jako określenie zarówno Boga jak i człowieka. Przypomina to stosowanie określenia šāpițum w literaturze akadyjskiej. Tak jak šāpițum posługuje się autorytetem przeniesionym na niego przez šarrum lub przez bóstwo, šôpẹt z Księgi Sędziów posiada pełnomocnictwo delegowane mu przez Jahwe, šôpèt kol-hā'āres („Sędzia całej ziemi” - Rdz 18, 25). To, że ktoś został wybrany przez Boga do spełniania funkcji sędziego, było wyrażone przez ducha Bożego, który zstępował na niego (Sdz 2, 16; 3, 9). Bóg posiadał władzę wyznaczania oraz usuwania sędziego (Ps 82, 1-8). Pozycja Jahwe jako šôpet par excellence porównywalna jest do kananejskiego bóstwa Ela, który innych bogów (Baala, Yamma i Mota) wyznaczał do spełniania funkcji sędziów pod swoją władzą ${ }^{11}$.

Głównym zadaniem, dla którego byli wyznaczani sędziowie, było utrzymanie pokojowych relacji między Izraelitami. Sędzia podejmował decyzje w razie zaistnienia sporu (Sdz 4, 5; $1 \mathrm{Sm} \mathrm{7,} \mathrm{15;} 2 \mathrm{Sm} \mathrm{15,} \mathrm{4).} \mathrm{Więk-}$ szość spraw, którymi musiał się zająć taki wybraniec, dotyczy opieki nad ubogimi, wdowami, sierotami oraz obcymi przybyszami (np. Ps 82; Jer 5, 28-29; 22, 15). Funkcje sędziów nie zawsze polegały na wydawaniu wyroków. Często występowali w roli arbitrów, to jest jako ci, którzy przywracali šâlôm, jaki panował przed wybuchem konfliktu lub najazdem wrogów (Rdz 16, 5; 19, 9; Sdz 11, 27). Z tego powodu, jeżeli ktoś był niezadowolony z wyroku uzyskanego od sędziego-człowieka, mógł wezwać interwencji Jahwe, najwyższego Sędziego (Ps 6, 7-9; Ps 82, 8). Ponieważ Bóg był zawsze sprawiedliwy, niewinna osoba, która czuła się niesłusznie skazana, mogła zwrócić się do niego osobiście, aby ją osądził ( $\check{s} p t)$, to jest „wyswobodził”, „obronił” lub „wynagrodził” według boskich kryteriów odpłaty (Ps 26, 1; Sdz 11, 27). Rdzeń špt zarówno w znaczeniu akadyjskim, jak i hebrajskim odnosi się także do „administrowania”, „rządzenia” lub „zarządzania” pewnym terytorium. Takie właśnie jest główne znacznie $\check{s} p t$ w Księdze Sędziów (Sdz 3, 10; 4, 4; 1 Sm 7, 6; ARM 1, 73: 45-53).

\footnotetext{
${ }^{10}$ T. L. J. MAFICO, Judge, Judging..., dz. cyt.

11 Tamże.
} 
Jak wspomniano już wcześniej, w akadyjskich tekstach z Mari, oprócz rządzenia na pewnym terytorium, šāpițum (sędzia) dowodził również armiami w walkach przeciwko wrogom króla (ARM 2, 98: 7-14). Funkcja ta przypomina rolę, jaką odgrywali sędziowie w przedmonarchicznym Izraelu: stali oni na czele wojsk i wyzwalali Izraelitów od ich ciemiężycieli oraz wrogów, np. Sdz 2, 16: „Jahwe wzbudził sędziów, którzy wyzwolili ich”; Sdz 3 , 10: „sprawował sądy nad Izraelem; wyruszył na wojnę”. W tym znaczeniu określenie $\check{s} p t$ odnosi się do „wyzwalania” lub „ratowania” (hebrajskie $\left.y \check{s}^{\prime}\right)^{12}$. Innym określeniem (stosowanym dla konkretnej osoby - Gedeona)

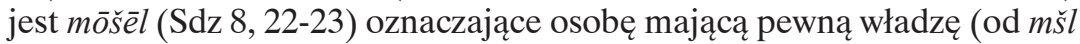
- podejmować decyzje, mieć władzę) $)^{13}$.

W Starym Testamencie, który został napisany przede wszystkim jako wskazówka prowadząca Izraelitów do ich Boga, termin špt (sądzić) nie był używany do określenia sprawowania sądów na podstawie prawa „cywilnego”. Bycie sędzią było funkcją boską, którą sam Jahwe delegował na tego, którego wyznaczył na przywódcę zarówno politycznego, jak i w zakresie spraw stricte sądowych. Dlatego byli oni zobowiązani do wypełniania swej funkcji sędziego w sposób bezstronny bez względu na status stron występujących w procesie (Wj 23, 2-3; Kpł 19, 15). Aby utrzymać czystość w rozpatrywanych sprawach, sędziowie byli upominani, aby nie dawali się przekupić, ponieważ łapówki oślepiały ich oczy (Iz 1, 23; 5, 23; 10, 1; Am 5, 12; 6, 12; Mi 3, 11; 7, 3; Prz 6, 19; 12, 17; 18, 15) ${ }^{14}$.

Jak wynika z powyższego, należy przyjmować, że sędziowie mieli pozycję podobną do książąt kananejskich, z którymi często musieli się spotykać chociażby podczas walk. Być może częściowo się na nich wzorowali, ale z jednym wyjątkiem - nie był to urząd dziedziczny. Nie znaczy to jednak, że synowie nie próbowali zająć miejsc swoich ojców, jak świadczy o tym opowiadanie o Abimeleku (Sdz 9).

Tradycyjnie sędziów dzieli się na tzw. większych (Otniel, Ehud, Debora i Barak, Gedeon, Jefte, Samson) i mniejszych (Tola, Jair, Jefte znajdujący się w obu grupach, Ibzan, Elon, Abdon), ale jest to podział sztuczny, zależny głównie od długości i stylu materiału literackiego zachowanego dla każdej z tych postaci. Nic nie świadczy o tym, aby sędziowie mniejsi mieli inną rolę niż więksi ${ }^{15}$. Biblia określa ich jako wybrańców Jahwe. Nie byli to więc zwykli

12 Tamże.

${ }^{13}$ G. W. Ahlström, The History of Ancient Palestine..., dz. cyt., s. 371-373.

${ }^{14}$ T. L. J. MAFicO, Judge, Judging..., dz. cyt.

${ }^{15}$ A. J. Hauser, The "Minor Judges” - A Re-evaluation, JBL 94 (1975), s. 191-199. E. T. Mullen Jr., The „Minor Judges“: Some Literary and Historical Considerations, CBQ 44 (1982), s. 185-201. A. Lods (Israel. From Its Beginning to the Middle of VIIIth Century, London 1996, 
ludzie - musieli posiadać charyzmę i zdolność narzucania swej woli innym ${ }^{16}$. Nie ma danych, które mogłyby dostarczyć informacji na temat częstotliwości występowania takich przywódców, ale też nie ma takich, które mogłyby świadczyć, że tacy przywódcy byli czymś wyjątkowym. Błędem byłoby sądzić, że tradycja zachowała imiona wszystkich przywódców w przedmonarchicznym Izraelu. Można wręcz sugerować, że taka forma przywództwa było dobrze znana w tym okresie, a poszczególne plemiona nie miały nic przeciw tej instytucji tak długo, jak nie naruszała pewnych norm ${ }^{17}$.

Sędziowie-kapłani. Przyjmując, że sędziowie rządzili jeden po drugim, otrzymuje się mało prawdopodobną liczbę ponad 400 lat. Zakładać więc można, że działali oni tylko na określonym, niezbyt wielkim terenie i byli sobie, przynajmniej częściowo, współcześni ${ }^{18}$. Szukając grup społecznych, spośród których mogłyby się wywodzić te niezwykłe osobowości, należy zwrócić uwagą na kastę kapłanów-Lewitów, którzy już wcześniej posiadali duże wpływy w Izraelu ${ }^{19}$. Wydaje się, że istnieje kilka informacji pozwalających powiązać te dwie grupy:

- Otniel, syn Kenaza ${ }^{20}$, młodszego brata Kaleba (Kaleb otrzymał Hebron - Joz 15, 13-15), zdobył Debir, za co dostał za żonę córkę Kaleba, Aksę $(15,17)$ - oba te miasta znajdują się wśród miast lewickich (spisy tych miast znajdują się w Joz 21, 1-42 i 1 Krn 6, 39-66). Często uważa się, że opowieść o podboju tych miejsc została napisana w celu podkreślenia uprawnień potomków Otniela-Kenizzyty do miejscowych źródeł wody, a być może również aby uprawomocnić ich roszczenia wobec potomków Kaleba ${ }^{21}$.

s. 334) odrzuca historyczność mniejszych sędziów uważając ich za eponimów klanów, o których „nic nie wiadomo oprócz ich miejsca pochówku, prawdopodobnie fikcyjnego”. B. LinDARS (The Israelite Tribes in Judges, [w:] Studies in the Historical Books of the Old Testament, ed. by J. A. EMERTon, Leiden 1979, s. 97-98 [SVT 30]) uważa sędziów za ludzi lokalnie awansowanych często w związku z ich czynami militarnymi.

${ }^{16}$ S. GrzyBeK, Okres „Sędziów” w dziejach Izraela, RBL 7 (1954), s. 13. Wg M. Grant (Dzieje dawnego Izraela, Warszawa 1991, s. 71) sędziowie „sprawując funkcje sądownicze zyskiwali sobie powszechny szacunek swą mądrością i bezstronnością”.

${ }^{17}$ N. P. LEMCHE, Early Israel. Anthropological and Historical Studies on the Israelite Society before the Monarchy, Leiden 1985, s. 277 (SVT 37).

${ }^{18}$ O. Eissfeldt (The Hebrew Kingdom, [w:] CAH, t. 2, cz. 2, s. 555) uznaje współczesność sędziów większych. Ich „mniejsi” koledzy mieliby być kolejnymi swymi następcami. B. Lindars (The Israelite..., dz. cyt., s. 98) uważa, że sędziowie sprawowali swe rządy kolejno - na starość jednak odchodzili na swego rodzaju emeryturę ustępując młodszym, ale zachowywali swą uprzywilejowaną pozycję we wspólnocie ze względu na wiek i doświadczenie.

${ }^{19}$ F. TRYL, Szukając pierwszych Izraelitów, ,Zeszyty Naukowe KUL” 44 (2002) nr 3-4, s. $52-57$.

${ }^{20}$ R. G. Boling, Othniel (Person), [w:] ABD, dz. cyt.

${ }^{21}$ A. Ofer, "All the Hill Country of Judah". From a Settlement Fringe to Prosperous Monarchy, [w:] From Nomadism to Monarchy, ed. by I. Finkelstein and N. Na'aman, Jerusalem 1994, s. 112. 
- Ehud, syn Gery ${ }^{22}$, Beniaminita - według Sdz 3, 26b-27 - „wrócił do Hasseira. Wróciwszy, zatrąbił w róg na górze Efraima”, co zapoczątkowało walkę z wrogami. Funkcja zwoływania ludu poprzez dęcie w trąby zastrzeżona jest tylko dla kapłanów; Lb 10, 8-10: „Gdy w waszym kraju będziecie wyruszać na wojnę przeciw nieprzyjacielowi, który was napadnie, będziecie przeciągle dąć w trąby”.

- Szamgar - narrator sam nie wiedział o nim zbyt wiele, a jego imię może być pochodzenia huryckiego, luwijskiego lub neohetyckiego ${ }^{23}$; określenie „ben Anat” (syn Anata) może wskazywać na arystokratyczne pochodzenie ${ }^{24}$. Imię Anat należy do kananejskiej bogini czczonej w Palestynie jeszcze przed przybyciem Izraelitów. Być może, że jego przodkowie, a nawet on sam należeli do czcicieli tej bogini ${ }^{25}$.

Należy tu wspomnieć o niezwykłym znalezisku z el-Khadr, miejscowości położonej na południe od Betlejem. Odkryto tam pięć grotów strzał, na których znajdowały się wyryte słowa. Na jednym z nich odczytać można bn 'nt (Ben Anat), natomiast na drugiej jego stronie ' $b d l^{l} b$ 't (strzała sługi lb't $)^{26}$ - trudno jednak przypuszczać, aby chodziło tutaj o tę konkretną postać biblijną.

Istnieje także możliwość, że jest to imię huryckie potwierdzone w tekstach z Nuzi. Szamgar byłby wtedy kimś w rodzaju najemnika, zawodowego żołnierza ${ }^{27}$.

- Debora, która „zasiadała pod Palmą Debory, między Rama i Betel w górach Efraima, dokąd przybywali Izraelici, aby rozsądzać swoje sprawy" $(\mathrm{Sdz} 4,5)$, oraz jej towarzysz (może nawet mąż ${ }^{28}$ ) Barak, syn Abinoama z Kadesz w pokoleniu Neftalego - miasto to jest jednym z lewickich miast ucieczki.

- Gedeon, syn Joasza z rodu Abiezera, z Ofra - jego ojciec według Sdz 6, 25 był rodzajem miejscowego, plemiennego kapłana posiadającego „ołtarz

${ }^{22}$ B. HalPern, Ehud (Person), [w:] ABD, dz. cyt.

${ }^{23}$ R. G. Boling, Shamgar (Person), [w:] ABD, dz. cyt.

${ }^{24}$ G. W. Ahlström (The History of Ancient Palestine..., dz. cyt., s. 378) przypuszcza, że mógł on pochodzić z kananejskiego rodu królewskiego.

${ }^{25}$ B. Mazar, Shamgar ben 'Anat, PEQ 66 (1934), s. 192-194. P. C. Craigie, A Reconsidering of Shamgar ben Anath, JBL 91 (1972), s. 239-240. F. C. Fensham, Shamgar ben 'Anat (Judg. 3, 31 and 5, 6), JNES 20 (1961), s. 197-198. A. VAn Selms, Judge Shamgar, VT 14 (1964), s. 294-304. R. G. Boling, Shamgar (Person), [w:] ABD, dz. cyt. O samej bogini Anat patrz U. Cassuto, The Goddess Anath, Jerusalem 1971.

${ }^{26}$ A. MAZAr, Archaeology of the Land of the Bible 10.000-586 B. C. E., New York 1990, s. 362.

${ }^{27}$ R. G. Boling, Judges, Garden City 1975, s. 89 (AB 7).

${ }^{28}$ Debora była żoną Lappidota; hebrajskie 'ešet lappidōt oznacza „ten, który rozbłysnął”. Imię to nie pojawia się ponownie, gdyż tradycja mogła go zapamiętać jako Baraka (,ten, który rozpala, rozświetla”) - za R. G. Boling, Judges, dz. cyt., s. 95. K. E. Lowery, Barak (Person), [w:] ABD, dz. cyt. 
Baala z Aszerą". W miejscu tym prawdopodobnie już wcześniej sprawowano kult jakiegoś bóstwa, którego przedłużeniem był kult Jahwe - Joasz jest imieniem jahwistycznym, natomiast drugie imię Gedeona, Jerubbaal, oznacza „Baal go chroni” i związane jest z kultem „pogańskim”29. Inną wskazówką pozwalającą łączyć go z kręgami kapłańskimi jest informacja, że ,jedna z drugorzędnych jego żon, mieszkająca w Sychem, urodziła mu syna" Abimeleka (Sdz 8, 31) - Sychem jest na liście miast ucieczki należących do lewitów. Jemu też pierwszemu zaoferowali Izraelici, aby sprawował nad nimi władzę ( $\mathrm{Sdz} 8,22)$. Czasami uważa się, że incydent ten miał miejsce w okresie przejściowym w kształtowaniu się władzy królewskiej ${ }^{30}$.

- Tola - brak wystarczających danych, aby powiedzieć coś więcej na temat jego pochodzenia ${ }^{31}$.

- Jair z Gileadu - niemal całkowity brak danych ${ }^{32}$.

- Jefte Gileadczyk - łączyć go można z równiną Jiftach-El na pograniczu Zabulona i Neftalego, ale jako swoją siedzibę wybrał Mispa, które jak wiele wskazuje, pełniło ważne miejsce w religii Izraelitów. Było to miejsce, gdzie sprawował swe sądy Samuel $(1 \mathrm{Sm} 7,16)$; tutaj zgromadziły się wojska izraelskie przed wyprawą przeciw Beniaminitom (Sdz 20, 1-3). Także wyboru Saula na króla dokonano w tym miejscu (1 Sm 10). Było to ważne sanktuarium jeszcze w okresie po niewoli babilońskiej ${ }^{33}$. Samo imię - yiptah'êl łączy go z kultem Ela.

- Ibsan z Betlejem - z tego miasta pochodzić miał także lewita zatrudniony przez Mikę w jego domowej świątyni (Sdz 17, 7-8); powstaje pytanie, czy Betlejem było także miastem, które zamieszkiwali kapłanilewici ${ }^{34}$. Według genealogii w 1 Krn 2, 51-54; 4, 4 mieszkańcy tego miasta powiązani byli z rodziną Kaleba.

- Elon Zabulonita pochowany został w Ajjalonie, mieście lewickim.

- Abdon, syn Hillela z Pireatonu - jego ród, jak wskazuje imię, można łączyć z miastem Abdon należącym do lewitów; być może chodzi tutaj

${ }^{29}$ B. Poniży, Pierwsze sanktuaria Izraela, [w:] Życie religijne w Biblii, red. G. Witaszek, Lublin 1999, s. 29. J. A. EMERTon, Gideon and Jerubbaal, JTS 27 (1976), s. 289-312. A. DŁugosz (Tekstualne trudności opowiadania o Gedeonie (Sdz 6-8), RBL 33 [1980], s. 269) podwójne imię Gedeona oraz niejahwistyczny kult w Ofra tłumaczy istnieniem różnych tradycji połączonych przez kompilatorów, którzy „nie zadali sobie trudu, by skrupulatnie dopasować i uzgodnić wszystkie różnice".

${ }^{30}$ N. M. SARna, Gideon, [w:] En. Jud., t. 7, k. 558.

${ }^{31}$ R. G. Boling, Tola (Person), [w:] ABD, dz. cyt.

${ }^{32}$ Tenże, Jair (Person), [w:] ABD, dz. cyt.

${ }^{33}$ B. Poniży, Pierwsze sanktuaria, s. 26-27.

${ }^{34}$ Możliwość taką zakłada m.in. J. de Moor, The Rise of Yahwism. The Roots of Israelite Monotheism, Leuven 1997, s. 39. 
o zwyczaj nazywania nowych osad (oraz zmiany nazw osad starych) imieniem eponima plemienia lub założyciela (np. Lb 32, 38) ${ }^{35}$.

- Samson z Sorea jest bohaterem ludowym w typie Herkulesa, o którym tak naprawdę nie wiadomo, czy istniał realnie, czy też stworzyła go wyobraźnia jakiegoś gawędziarza ${ }^{36}$; może też łączyć w sobie cechy kilku postaci odpowiednio podkolorowane - chociaż nie brak głosów uznających jego historyczność ${ }^{37}$. Imię łączy go z kultem Šamaša, boga Słońca ${ }^{38}$, i sugerować może jego związki z miastem Bet Szemesz (Dom-Świątynia Šamaša), które należało do lewitów.

- Heli - Biblia wyraźnie wskazuje, że pełnił funkcje kapłańskie rządząc Izraelem przez całe pokolenie, tj. ok. 40 lat $(1 \mathrm{Sm} \mathrm{4,18).} 1 \mathrm{Sm} \mathrm{3,1}$ stwierdza, że „słowo Jahwe było rzadkie w tych dniach”, co próbuje się odczytać w ten sposób, że religia, którą chciałby widzieć pisarz biblijny, jeszcze nie istniała w całym kraju - samo imię Helego świadczy, że był on czcicielem bóstwa 'ly (Ela) $)^{39}$.

- Samuel z Ramataim (Rama), syn Elkana, syna Jerochama, syna Elihu - według 1 Krn 6, 12 jest to ród kapłanów-lewitów z linii Kehatytów.

Jak wskazuje na to powyższa analiza, zdecydowaną większość sędziów, zwłaszcza tych, o których Biblia podaje więcej informacji, można wyraźnie powiązać z kręgami kapłańskimi. Trudno jednak przypuszczać, aby byli oni kapłanami Jahwe (patrz niżej).

Działalność sędziów. Do niedawna przyjmowano hipotezę M. Notha, że Izraelici w okresie sędziów zorganizowani byli w konfederację na wzór greckiej amfiktionii. Spotkała się ona jednak z druzgocącą krytyką. Egejski pierwowzór powstał nie wcześniej jak w VIII wieku przed Chr., a najwcześniejsze wiarygodne świadectwo dla tego terminu pochodzi dopiero z wieku IV przed Chr. Celem tego związku była opieka nad wspólnymi interesami, prawami międzynarodowymi i wspólna obrona centralnej świątyni ${ }^{40}$. W Izra-

${ }^{35}$ M. Weinfeld (The Pattern of the Israelite Settlement in Canaan, [w:] Congress Volume, Jerusalem 1986, Leiden 1988, s. 279 [SVT 40]) porównuje ten zwyczaj z podobnym, stosowanym w Grecji w okresie kolonizacji, np. Herodot IV 247, 4.

${ }^{36}$ J. Blenkinsopp, Structure and Style in Judges 13-16, JBL 82 (1963), s. 65-76. P. NeL, The Riddle of Samson, Bb 66 (1985), s. 534-545.

${ }^{37}$ M. Grant (Dzieje dawnego Izraela..., dz. cyt., s. 88) uważa go za przywódcę „izraelskiego ruchu oporu”. A. Lemaire (Dzieje biblijnego Izraela, Poznań 1998, s. 20) stwierdza, że legenda o Samsonie odzwierciedla tradycję regionu Bet Szemesz, gdzie zamieszkiwało kilka rodów danickich współżyjących z Filistynami.

${ }^{38}$ J. L. Crenshaw, Samson, [w:] ABD, dz. cyt.

${ }^{39}$ G. W. Ahlström (The History of Ancient Palestine..., dz. cyt., s. 390) przypuszcza, że władza Helego mogła rozwinąć się po śmierci Abimeleka.

${ }^{40}$ N. P. Lemche, The Greek “Amphictiony”- Could Be a Prototype for the Israelite Society in the Period of the Judges?, JSOT 4 (1977), s. 49-59. 
elu centralne sanktuarium musiałoby spełniać następujące warunki: obecność Arki Przymierza, uznanie ze strony wszystkich plemion sanktuarium jako ich najważniejszego miejsca świętego, jakieś świadectwa obchodzenia tam wspólnych uroczystości. Żadne z proponowanych miejsc (Sychem, Betel, Gilgal, Szilo) nie spełnia tych warunków ${ }^{41}$.

Jednak nawet najwięksi oponenci jakichkolwiek form organizacji Izraela w okresie sędziów przyznają, że powstanie monarchii poprzedzało istnienie wspólnej świadomości, na której zbudowano później zjednoczone państwo ${ }^{42}$. Wyrazem tego mogły być religijno-militarne konfederacje, które miały wpływ na poczucie pewnej jedności i odrębności ${ }^{43}$. Musieli istnieć wodzowie, których kierownictwo uznawano powszechnie w okresie kryzysu lub niebezpieczeństwa ${ }^{44}$. Takimi osobami mogli być sędziowie - przywódcy wojskowi i kapłani, którzy występowali, kiedy zstępował na nich „duch Jahwe" (rûah YHWH). Organizowali oni lokalne przymierza plemion i stawali na ich czele; czasami mogli nawet organizować krótkotrwałe państewka, np. Ibsan posiadał 30 synów i 30 córek; córki wydał za mąż poza swoim terytorium; także dla synów sprowadził obce żony ( $\mathrm{Sdz} 12,8-9)$, co można uważać za sposób prowadzenia polityki międzynarodowej. Jairowi podlegało 30 miast (Sdz 10, 4), które nazywano „Osiedlami Jaira” co świadczy, że był on władcą terytorialnym w Gileadzie. Abdon posiadał 40 synów i 30 wnuków, którzy podróżowali na grzbietach osłów (Sdz 12, 14) - zwykli ludzie nie mieli takiego prawa, osły były zwierzętami transportowymi, a dosiadać je mogły tylko osoby z rodów królewskich ${ }^{45}$. Tak więc Izrael stanowił prawdopodobnie związek niewielkich i często krótkotrwałych władztw terytorialnych ${ }^{46}$.

${ }^{41}$ A. D. H. MAYEs, Israel in the Pre-Monarchy Period, VT 23 (1973), s. 157-161.

${ }^{42}$ Tamże, s. 167. A. O. Mojola (The "Tribes" of Israel? A Bible Translator's Dilemna, JSOT 81 (1998), s. 15-29) uważa, że przedmonarchiczny Izrael miał wszystkie cechy jednolitej grupy etnicznej - samoodradzającej się biologicznie i o tej samej kulturze; stąd grupy wchodzące w jego skład były tylko klanami.

${ }^{43}$ S. Grosby, Kinship, Territory, and the Nation in the Historiography of Ancient Israel, ZAW 105 (1993), s. 7.

${ }^{44}$ W. F. Albright, Od epoki plemiennej do chrześcijaństwa, Warszawa 1967, s. 229-130.

${ }^{45}$ G. W. Ahlström (The History of Ancient Palestine..., dz. cyt., s. 374). R. G. Boling (Judges..., dz. cyt., s. 188) uważa, że „synowie” sędziów mają charakter symboli, pod którymi kryją się członkowie lokalnych konfederacji.

46 J. WARZECha (Dawny Izrael, t. 1: Od Abrahama do Salomona, Warszawa 1995, s. 90) przyjmuje za „aktualnie najbardziej prawdopodobną” hipotezę F. Crüsemanna - stwierdzająca, że Izrael stanowił społeczność segmentaryczną - zbudowaną na podstawie historycznego zastosowania badań antropologicznych, porównujących przedmonarchiczny Izrael do ludów afrykańskich, gdzie brak jest władzy centralnej; społeczność ta jest podzielona pomiędzy grupy o równym statusie, gdzie „rodziny i rody mogły zachować swoją niezależność”. Przeciwnikiem tej hipotezy jest J. W. Rogerson (Was Israel a Segmentary Society?, JSOT 36 [1986], s. 17-26). 
Izrael był w tym okresie ludem bardzo dynamicznym - z pierwotnych siedzib na Pogórzu centralnym, korzystając z wszelkich możliwych sposobów, rozpoczął ekspansję na tereny sąsiednie kolonizując m.in. Judę, której część mieszkańców była co prawda pochodzenia miejscowego, ale część stanowili przybysze z północy ${ }^{47}$. Podobnie zapewne było z Danitami, którzy po długotrwałej wędrówce znaleźli swą ostateczną siedzibę w Galilei. Wiarygodność tego opowiadania potwierdza archeologia - w tym okresie pojawiają się tam duże naczynia zasobowe (collared-rim jars) pospolite w Palestynie centralnej, ale niemal nieznane wcześniej na północy ${ }^{48}$. Możliwy jest nawet powrót części Izraela na tereny Zajordania, jak świadczy o tym opowieść o okupowaniu terenów na wschód od Jordanu przez Gedeona ( $\mathrm{Sdz} 8,4-21)$. Natomiast parcie na zachód mogło być bezpośrednią przyczyną starcia z Filistynami.

Powyższemu procesowi towarzyszyło inne zjawisko: następował stopniowy zanik niewielkich wiosek na rzecz większych osad typu miejskiego. Miasta zazwyczaj tworzą się, gdy ludność wiejska organizuje się przeciw innym społecznościom lub w okresach złej koniunktury. Mur zbudowany w celach obronnych staje się symbolem wspólnoty, która broni czegoś więcej niż tylko samej ziemi - tworzy się inna mentalnośćc ${ }^{49}$. W Izraelu taki mur rozwinął się prawdopodobnie z ciągu domów zbudowanych na skraju osady, które stopniowo zamykały okrąg tworząc linię obronną. Powstał tzw. mur kazamatowy składający się z dwóch ciągów murów, między którymi znajdowała się wolna przestrzeń podzielona na komory, które wypełniano następnie kamieniami i ziemią. Komory przy podstawie budowli służyły jako magazyny. Mury tego typu znano już w okresie Średniego Brązu II (np. Hazor, Sychem, Tanaak), jednak zostały twórczo rozwinięte, tak że

${ }^{47}$ A. Ofer, "All the Hill Country of Judah"..., art. cyt., s. 107-108.

${ }^{48}$ A. Mazar, Archaeology..., dz. cyt., s. 335. Z. Kallai (A Note on the Twelve-Tribe Systems of Israel, VT 49 [1999], s. 126) uważa, że wędrówkę Danitów potwierdza porządek, w jakim wyliczone są plemiona w Pieśni Debory, gdzie zastosowano specjalną technikę pisarską - według listy plemion Dan znajduje się na północy, natomiast szczegóły topograficzne odpowiadają terenom południowym. Ma to odzwierciedlać wędrówkę plemienia z południa na północ. Sama wędrówka opisana jest według pewnego schematu przypominającego wędrówkę Izraelitów do Ziemi Obiecanej - za A. Malamat (The Danite Migration and the Pan-Israelite Exodus-Conquest - A Biblical Narrative Pattern, Bb 51 [1970], s. 1-16).

${ }^{49}$ H. J. Franken, Osadnictwo, [w:] Archeologia Palestyny, pod red. L. W. Stefaniaka, Warszawa 1973, s. 464. W. G. Dever (Archaeology, Urbanism, and the Rise of the Israelite State, [w:] Urbanism in Antiquity: From Mesopotamia to Crete, ed. by W. E. Aufrecht, N. A. Mirau \& S. W. Gauley, Sheffield 1997, s. 181 [Journal for the Study of the Old Testament. Supplement Series, 244]) zaznacza, że powstanie miast zawsze poprzedzało powstanie państw, chociaż taka urbanizacja nie jest jednak warunkiem sine qua non powstania państwowości. 
w X wieku przed Chr. domy przylegające do umocnień budowano w taki sposób, aby tylne pomieszczenie stanowiło integralną część muru ${ }^{50}$.

W procesie kolonizacyjnym napotykano podobną działalność prowadzoną przez inne ludy: Ammonitów, Moabitów, Amalekitów, którzy wycofywali się z terenów pustynnych na bardziej urodzajne obszary. Starcie było więc nieuniknione. Dodatkowo sytuację komplikowały kananejskie enklawy w regionach teoretycznie już izraelskich, których spis znajduje się w Sdz 1 i jak się uważa, zawarte tu informacje mogą rzeczywiście odpowiadać opisywanej sytuacji ${ }^{51}$. Y. Kaufman na podstawie opisów biblijnych wyróżnił trzy rodzaje wojen prowadzonych przez Izraelitów:

1. walki związane z podbojem Kanaanu (od Lb 21 do Sdz 1), chronologicznie najwcześniejsze;

2. wojny plemienne (Sdz 1-2);

3. walki obronne przeciw napierającym wrogom ${ }^{52}$.

Walczono z królem Aramu, Kuszan-Riszeataimem, który mógł pochodzić z północnej Mezopotamii lub wschodniej Syrii ${ }^{53}$ (Otniel); Eglonem, władcą Moabu (Ehud); Jabinem, królem Kanaanu, oraz wodzem jego wojsk Siserą, który być może wywodził się z jednego z Ludów Morza ${ }^{54}$ (Debora i Barak); Madianitami (Gedeon); Ammonitami (Jefte) oraz Filistynami (Samson, Heli, Samuel).

Najlepiej znaną wojną z tego okresu jest starcie z Kananejczykami dowodzonymi przez Siserę, barwnie opisane w Pieśni Debory (Sdz 5), która - jak się uważa - powstała niedługo po opisanych w niej wydarzeniach ${ }^{55}$. Różne są przypuszczenia na temat tego, co było bezpośrednim powodem starcia. J. D. Schloen zakłada, że plemiona izraelskie, sprzymierzone z Madianitami, zaangażowane były w handel karawanowy i była to walka w ochronie szlaków blokowanych przez wojska Sisery ${ }^{56}$. Inną hipotezą jest przypuszczenie A. Troniny, że powodem starcia było przerwanie przez

${ }^{50}$ Y. SHILOH, The Casemate Wall, the Four-Room House, and Early Planning in the Israelite City, BASOR 268 (1987), s. 8-10.

${ }^{51}$ U. Szwarc, Kompozycja literacka Sdz 1, RTK 36 (1989) nr 1, s. 15. Natomiast G. A. Auld (Judges I and History: A Reconsideration, VT 25 (1975), s. 261-285) uważa, że Sdz 1 stanowi raczej późną kompilację tradycji wywodzących się z południa kraju (która częściowo przepisana jest z Księgi Jozuego).

${ }^{52}$ G. Bacon, Judges, the Book of, [w:] En. Jud., t. 10, k. 443.

${ }^{53}$ R. G. Boling, Judges..., dz. cyt., s. 81.

${ }^{54}$ Tamże, s. 94.

${ }^{55}$ S. Grzybek (Rekonstrukcja tekstu Pieśni Debory (Sędz. roz. 5), RBL 8 [1955], s. 3) uważa, że była to pieśń ludowa ułożona przez przygodnego autora powstała w okresie formowania się państwa izraelskiego.

${ }^{56}$ J. D. Schloen, Caravanes, Kenites, and Casus Belli: Enmity and Alliance in the Song of Deborah, CBQ 55 (1993), s. 19-21. 
Kananejczyków łączności między Palestyną środkową i Galileą oraz to, że przejęli oni kontrolę nad Doliną Jezreel ${ }^{57}$. Jednak bez względu na powód była to jedna z niewielu akcji, w której brało udział kilka plemion występujących wspólnie i odniosły one sukces ${ }^{58}$. Mógł to być punkt zwrotny, po którym nastąpiło stopniowe scalenie plemion zdających sobie sprawę, że tylko wspólne akcje gwarantują powodzenie ${ }^{59}$. W walkach prowadzonych przez Izrael mogły brać udział także inne ludy, które nie zostały później włączone do schematu 12 plemion, który miałby być podstawą wspólnoty ${ }^{60}$. Mogło być też tak, że w pewnych okresach było więcej lub mniej plemion niż 12. Prawdopodobnie dopiero pod koniec tego okresu ukształtowała się lista plemion izraelskich, jaką zawiera ostateczna wersja Biblii ${ }^{61}$. Należy tu podkreślić, że opisy granic plemiennych są prawie zawsze w zgodzie z podstawowymi naturalnymi granicami regionów. Co ciekawe, terytoria plemienne kilku grup odpowiadają przedizraelskim granicom miast-państw, np. Zabulon - Jokneam; Issachar - Megiddo ${ }^{62}$. Jednak część badaczy uważa, że mapa plemion wzorowana jest na okręgach utworzonych przez Salomona, gdyż tylko wówczas państwo osiągnęło rozmiary obejmujące tereny, które przypisuje się działom plemiennym Izraela ${ }^{63}$.

Zagrożenie zewnętrzne było ważnym czynnikiem zbliżającym poszczególne plemiona. Armia izraelska w tym okresie stanowiła rodzaj

${ }^{57}$ A. Tronina, Rekonstrukcja tekstu Pieśni Debory (Sdz 5), [w:] Studium Scripturae anima theologiae. Prace ofiarowane Księdzu Profesorowi Stanisławowi Grzybkowi, red. J. Chmiel, T. Matras, Kraków 1990, s. 338.

58 A. Malamat, The War of Gideon and Midian: A Military Approach, PEQ 85 (1953), s. 61-65.

${ }^{59}$ A. D. H. MAYEs, The Historical Context of the Battle against Sisera, VT 19 (1969), s. 355-356.

${ }^{60}$ N. P. Lemche ("Israel in the Period of the Judges" - the Tribal League in Recent Research, StTh 38 (1984), s. 16-20) na podstawie list plemion wyróżnił ich dwa typy: listę A, która obejmuje Lewitów, ale nie ma w niej Efraima i Menassesa, na miejscu których jest plemię Józefa; lista B wyodrębnia Lewitów, a zamiast Józefa jest Efraim i Menasses. Lista B mogła powstać w okresie między 1000 a 722 r. przed Chr. Z. Kallai (The Twelve-Tribe Systems of Israel, VT 47 [1997], s. 65) uważa, że podział Józefa na dwa plemiona - Efraima i Menassesa oraz uprzywilejowany status pierwszego z nich może odpowiadać realiom historycznym.

${ }^{61}$ J. de Moor (The Twelve Tribes in the Song of Deborah, VT 43 [1993], s. 493) stwierdza, że oryginalny porządek zawarty w Pieśni Debory jest taki sam jak ten w genealogii synów Jakuba w Księdze Rodzaju. Został on zmieniony na krótko po podziale kraju aby odpowiadać nowej sytuacji politycznej.

${ }^{62}$ Z. GAL, Cabul, Jiphtah-El and the Boundary between Asher and Zebulon in the Light of Archaeological Evidence, ZDPV 101 (1985), s. 127.

${ }^{63}$ Z. KALLAI, The United Monarchy of Israel - A Focal Point in Israelite Historiography, IEJ 27 (1977), s. 104-106. N. K. GotTwaLd (The Tribes of Yahweh: A Sociology of the Religion of Liberated Israel 1250-1050 B. C. E., Maryknoll 1985, s. 362-363) uważa, że schemat 12 plemion wprowadził Dawid dla celów administracyjno-wojskowych. 
milicji mobilizowanej przez przywódcę w razie wrogiego najazdu. Natura zagrożenia (były to głównie najazdy grup zajordańskich) powodowała, że nacisk odczuwała tylko część Izraela i nie stanowiło to groźby dla plemion sąsiednich. Dopiero gdy zagrożone było kilka terytoriów plemiennych, dochodziło do wspólnej akcji ${ }^{64}$.

Konflikty wewnętrzne. Izrael nie zawsze występował przeciwko wrogom zewnętrznym, zdarzały się także konflikty wewnętrzne. Jedna z takich wojen, opisana w Sdz 19-21, wybuchła, gdy Beniaminici dopuścili się przestępstwa względem lewity, co świadczyć może o szacunku, jakim darzono kapłanów-lewitów. Jeśli oczywiście założyć, że opis odpowiada rzeczywistym wydarzeniom ${ }^{65}$. Innym takim zdarzeniem jest starcie z Efraimitami (Sdz 12). Świadczy to, że organizacja plemienna nie była w stanie opanować sił odśrodkowych oraz wewnętrznych rywalizacji, które często prowadziły do starć zbrojnych ${ }^{66}$. Było to główną słabością Izraela stojącego wobec sąsiednich ludów zorganizowanych w monarchie ${ }^{67}$. W grę wchodzić mogły także różnice w łonie samego Izraela, gdzie plemiona z centralnego i północnego Pogórza walczące z Kananejczykami z równin, których podstawą ekonomii było rolnictwo (Efraim, Beniamin, Machir, Issachar, Zebulon i Neftali), posiadały więcej cech wspólnych z ludami nieizraelskimi niż z członkami plemion, którzy zależni byli od handlu morskiego (Aszer i początkowo Dan) lub od wyspecjalizowanego pasterstwa (Ruben i Gad) ${ }^{68}$.

Religia sędziów. Trudno określić religię wyznawaną wówczas w Izraelu. Wydaje się jednak, że czczono bóstwa będące patronem najważniejszej rodziny w danej wspólnocie. Np. rodzina Gedeona (Jerubbaala) posiadała

${ }^{64}$ C. Meyers, Of Seasons and Soldiers: A Topological Appraisal of the Premonarchic Tribes of Galilee, BASOR 252 (1983), s. 53-55.

${ }^{65}$ S. S. BRooks (Was There a Concubine at Gibeah?, BAIAS 15 [1996], s. 37-38) datuje tę wojnę na okres między upadkiem Saula i koronowaniem Dawida.

${ }^{66}$ J. BRIGHT, Historia Izraela, Warszawa 1994, s. 184.

${ }^{67}$ C. Schedl (Historia Starego Testamentu, t. 2: Lud Bożego Przymierza, Tuchów 1995, s. 229) uważa, że wynikało to z przywiązania Izraelitów do wolności i swej partykularnej odrębności.

${ }^{68}$ L. E. STAGER, Archaeology, Ecology, and Social History: Background Themes to the Song of Deborah, [w:] Congress Volume, Jerusalem 1986, Leiden 1988, s. 224 (SVT 40). Według J. S. Ackerman (Prophecy and Warface: Study of Deborah-Barak Story, BASOR 220 [1975], s. 10) czynnikiem łagodzącym spory była działalność tzw. $n^{e} b \hat{\imath}$ îm, którzy podtrzymywali ducha wspólnoty, a także zagrzewali do walki przed bitwami z wrogiem. Według opisów w 1 Sm 10 i 19 grając na instrumentach wpadali oni w rodzaj ekstatycznego szału, w którym pozostawali długi czas i w czasie którego ,prorokowali”. J. Jelito (Historia czasów Starego Testamentu, Poznań 1961, s. 190) uważa ich za poprzedników późniejszych proroków przemawiających do ludu w imieniu Jahwe. Natomiast S. Frolov i V. Orel (Gods of Israel. The Religious Pluralism in the Times of Saul and David, BeO 39 [1997], s. 25) uważają, że obie grupy nie miały ze sobą nic wspólnego. 
w Ofra świątynię na szczycie wzgórza, która miała wyposażenie typowe dla lokalnego sanktuarium: ołtarz (Sdz 6, 20-24), drzewo (terebint - 6, 11) służące jako aszera oraz złoty „efod” o wadze 1700 sykli $(8,24-27)$. Wyposażenie to może świadczyć o bogactwie miasta, a zwłaszcza rodziny Gedeona. Ponieważ wszyscy jego mieszkańcy należeli do klanu Abiezerytów, świątynia musiała spełniać funkcję sanktuarium klanowego.

Podobnie opowiadanie o sanktuarium w Rama Sufitów (1 Sm 9, 1-10; 16) na terytorium Beniamina nie świadczy, że znano tam kult Jahwe, jaki rozwinął się później. Usytuowane zaraz za bramą miasta w punkcie wyraźnie powyżej poziomu samego miasta, tworzyło rodzaj wyżyny (bāmôt); posiadało też budynek $(9,22)$ z ławkami wokół ścian przeznaczonymi do uczt kultowych ${ }^{69}$.

Najbardziej bulwersującą kwestią dotyczącą religii tego okresu jest opowiadanie o ślubie Jeftego, czy też raczej o jego wykonaniu: była to ofiara z własnej córki złożonej dla Jahwe (Sdz 11, 30-40). Czasami starano się złagodzić wymowę tego rytuału twierdząc, że chodziło tu jedynie o konieczność pozostania dziewczyny w stanie panieńskim, jednak szczegółowa analiza tekstu wskazuje, że chodzi tu rzeczywiście o ofiarę złożoną z człowieka ${ }^{70}$. Wydaje się, że ani sam Jefte, ani jemu współcześni, ani nawet narrator nie widzieli w tym postępku niczego złego - Sdz 11, 29 stwierdza, że nadal „duch Jahwe był nad Jeftem”; ofiary z ludzi zdarzały się prawdopodobnie częściej i nie były uważane za sprzeczne z wolą Boga (np. w Rdz 22, 1-19 Jahwe żąda od Abrahama ofiary z jego syna Izaaka). Sama przysięga była pospolitą praktyką w świecie starożytnym ( Rdz 28, 20 22; $1 \mathrm{Sm} \mathrm{1,} \mathrm{11;} 2 \mathrm{Sm} \mathrm{15,8)} \mathrm{i} \mathrm{należało} \mathrm{ją} \mathrm{wypełnić} \mathrm{(Lb} \mathrm{30,} \mathrm{3;} \mathrm{Dtr} \mathrm{23,} \mathrm{22-24).}$ Jefte jest tu ukazany jako bohater tragiczny; może być zwycięskim sędzią, ale nie jest modelem idealnego Izraelity ${ }^{71}$ - ofiary takie były zakazywane przez prawo i proroków (Dtr 18, 10; Jer 7, 31; 19, 5).

Pomimo że Księgę Sędziów cechuje różnorodność gatunków literackich $^{72}$, wydaje się, że można odkryć w niej pewną prawidłowość. Wcześni

${ }^{69}$ K. van der Toorn, Family Religion in Babylonia, Syria and Israel: Continuity and Change in the Forms of Religious Life, Leiden 1996, s. 252-254 (SHCANE 7).

${ }^{70}$ S. GrZYBEK, Starotestamentowe ofiary w ludziach a ślub Jeftego, RBL 9 (1956), s. 20. T. C. Römer (Why Would the Deuteronomist Tell about the Sacrifice of Jephthah's Daughter?, JSOT 77 [1998], s. 27-39) uważa jednak, że opowieść o ofierze z córki Jeftego wzorowana jest na dramatach Eurypidesa, gdzie jej odpowiedniczką jest Ifigenia, córka Agamemnona. Autor był zwolennikiem kultury greckiej, a swoje dzieło włączył do Księgi Sędziów jako „krytykę oficjalnej teologii deuteronomistycznej".

${ }^{71}$ T. A. LenchaK, Puzzling Passages: Judges 11, 30-31, TBT 38 (2000), s. 248.

72 J. S. SYNowiec (Izrael..., dz. cyt., s. 106-117) wyróżnia opowiadania o bohaterach, legendy, opowiadania ludowe, opowiadania etiologiczne, sprawozdania historyczne, zagadki, genealogie, wykazy, itineraria, zapisy, mowy polityczne, wyrocznia, mowy Jahwe, mowy anioła Jahwe, modlitwy i utwory poetyckie. 
sędziowie zmagali się z najazdami słabo zorganizowanych ludów Transjordanii i Negewu - Ammonitami, Amalekitami, Madianitami; później na arenę wkraczają Filistyni - dobrze zorganizowani, urodzeni wojownicy, z którymi walczy półmityczny Samson, ale nie potrafi on ostatecznie ich wypędzić z ziemi Izraela - to oni pokonują sędziego. W okresie Helego i Samuela Izraelitom grozi całkowite podporządkowanie nadmorskim sąsiadom - paląca staje się konieczność ustanowienia jednego ośrodka władzy, z którego można by było kierować walką wielu plemion.

\section{Początki monarchii}

Jedną z ważniejszych przyczyn powstania zjednoczonego państwa był duży wzrost liczby ludności oraz obszarów przez nią zamieszkanych. Powodowało to, że obrona przeciwko wrogom zarówno zewnętrznym, jak i wewnętrznym stawała się trudniejsza. Dane antropologiczne świadczą, że układy o współpracy w celach obronnych zawierane są głównie pomiędzy niewielkimi wspólnotami. Gdy wzrastała ich liczebność, taka współpraca stawała się trudniejsza z dwóch przyczyn:

- każdy członek wspólnoty słusznie widział swój potencjalny w niej udział jako mniej ważny w stosunku do wysiłku całej społeczności, chociaż ponosił pełne koszty indywidualnego udziału;

- większa liczba członków zwiększała koszty wspólnych przedsięwzięć. Przymus stosowany przez instytucje władzy redukował te ostatnie koszty, a każdy członek wspólnoty chętniej brał udział we wspólnych zadaniach, jeżeli czyniły to także inne osoby. Ponadto produkcja żywności organizowana przez władzę powodowała, że straty wynikające $\mathrm{z}$ wrogich najazdów oraz kradzieży były mniejsze. Wynikiem tego był wzrost produkcji i zwiększenie się powierzchni użytków rolnych - zaspokajało to rosnący głód ziemi ${ }^{73}$.

Samuel. Ostatnim i jak się często uważa najwybitniejszym sędzią był Samuel, który stał się kreatorem pierwszego króla w Izraelu, co zapoczątkowało z kolei ostateczne przekształcenie się luźnej wspólnoty w naród świadomy swej jedności i odrębności. Pomimo że imię jego pojawia się w Biblii 122 razy, to wyrażenie špt (sądzić) połączone z Samuelem występuje tylko w 3 przypadkach ${ }^{74}$. Pomijając problem jego historyczności, która jest często kwestionowana, trudno zbyt wiele powiedzieć na temat jego osoby,

${ }^{73}$ R. F. Muth, Economic Influences on Early Israel, JSOT 75 (1997), s. 88-89.

${ }^{74}$ J. ŁACH, Samuel - ostatni sędzia i prorok Izraela, RBL 20 (1967), s. 334. F. A. SPINA (Eli's Seat: The Transition from Priest to Prophet in 1 Sam 1-4, JSOT 62 [1994], s. 67-75) sugeruje, że już zasiadanie Helego na krześle miało symboliczny charakter władzy królewskiej lub sędziowskiej. 
określić zakres jego władzy oraz terytorium, jakie mu podlegało. $1 \mathrm{Sm} 7$ ukazuje Samuela sprawującego swe rządy z głównej siedziby w Rama, skąd wyruszał do Mispa, Betel i Gilgal, gdzie sądził lud. Stąd prawdopodobne wydaje się, że miasta te były rodzajem centrów administracyjnych państewka, które rozciągało się na niewielkim terytorium ${ }^{75}$.

Był to jednak okres, kiedy przeżywała się stara formuła władzy przywódców niewielkich jednostek terytorialnych. Ekspansja Filistynów w kierunku centralnego Pogórza Palestyny stanowiła zagrożenie dla całej miejscowej ludności. Zaistniała potrzeba stworzenia jednolitej władzy państwowej zdolnej pokierować walką. Władzę taką gotowa była poprzeć także powstająca wówczas warstwa posiadaczy ziemskich oraz elit miejskich, która dbała o własną pozycję i dążyła do zabezpieczenia się przed niebezpieczeństwem zarówno zewnętrznym, jak iwewnętrznym ze strony ludności ubogiej, dla której zaczynało brakować ziemi uprawnej $^{76}$. Początkowo, jak mówi Biblia, funkcję taką sprawował Samuel, któremu udało się nawet przynajmniej raz pokonać Filistynów w bitwie pod Mispa (1 Sm 7, 7-14). „Kiedy jednak Samuel się postarzał” (8, 1), kwestia jego następcy znowu stała się paląca. Został nim Saul.

Pierwszy władca Izraela. Wyznaczenie władcy nie było zwyczajem normalnym w starożytności - udokumentowane jest to jedynie w przypadku władców hetyckich. Próbuje się to także porównywać do sposobu wyznaczania władców kananejskich będących równocześnie lennikami faraona - byli oni także powoływani po upadku władzy egipskiej. Powołani w ten sposób władcy byli niejako primus inter pares, a władza przez nich sprawowana była do pewnego stopnia ograniczona $^{77}$. Wybicie się i sukces przywódcy wiąże się z jego autorytetem, charyzmą ${ }^{78}$, tym samym to wspólnota wybiera swego wodza i staje się od niego zależna. Jednocześnie przywódca jest zależny od wspólnoty do momentu, gdy jego funkcja zostanie zinstytucjonalizowanym urzędem ${ }^{79}$.

Istniały trzy tradycje powołania pierwszego władcy izraelskiego: opowieść o spotkaniu młodego Saula z anonimowym człowiekiem, gdy poszukiwał on oślic swego ojca (1 Sm 9); druga o losowaniu władcy w Mispa (19, 17-27); trzecia o proklamowaniu go przez lud w Gilgal $(11,15)^{80}$. Najstarszą

${ }^{75}$ G. W. Ahtström, The History of Ancient Palestine..., dz. cyt., s. 426.

${ }^{76}$ I. Finkelstein, The Emergence of the Monarchy in Israel: The Environmental and Socio-Economic Aspects, JSOT 44 (1989), s. 52-53.

${ }^{77}$ D. J. McCARTHY, Compact and Kingship: Stimuli for Hebrew Covenant Thinking, [w:] Studies in the Period of David and Solomon and Other Essays, ed. by T. Ishida, Winona Lake 1982, s. 80-81.

${ }^{78}$ W. BeYerlin, Das Königscharisma bei Saul, ZAW 73 (1961), s. 186-201.

${ }^{79}$ J. W. Flanagan, Chiefs in Israel, JSOT 20 (1981), s. 50.

${ }^{80}$ J. M. Miller (Saul's Rise to Power: Some Observations Concerning 1 Sam 9, 1-10; 10 , 26-11; 15 and 13:2-14: 46, CBQ 36 [1974], s. 159-172) uważa, że jest to mieszanka opowieści 
z tych opowieści wydaje się być ta ostatnia, gdzie wybór dokonany jest przez lud; elekcja w Mispa jest najprawdopodobniej dodatkiem Deuteronomisty, który rozbił fabułę na dwie części ${ }^{81}$. Na historię o powołaniu monarchii kładzie się cieniem tradycja niechętna tej instytucji; ona też nadaje ton dalszym opowiadaniom stawiającym Saula w złym świetle ${ }^{82}$.

Istnieją różne hipotezy, dlaczego to właśnie Saul został wybrańcem. Jego atutem miałoby być pochodzenie z niewielkiego plemienia Beniamina, co miałoby go zabezpieczać przed zawiścią ze strony innych plemion ${ }^{83}$. Wydaje się to jednak mało prawdopodobne; większe znaczenie miał tu raczej fakt, że Beniaminici, których terytorium położone było w centrum kraju, stanęli w obliczu bezpośredniej agresji filistyńskiej ${ }^{84}$. Sam Saul mógł zaczynać swoją karierę jako władca niewielkiego państewka z centrum w Gibeonie, skąd rozpoczął ekspansję na terytoria sąsiednie. Jego władzy podlegały obszary Efraima i Beniamina; słabo związane z centrum były północne tereny Samarii, dolina Jordanu i część centralnej Transjordanii ${ }^{85}$.

Po pierwszych zwycięstwach Saul przystąpił do pewnej konsolidacji swojego władztwa. Jako swoją główną siedzibę, swego rodzaju pierwszą stolicę, wybrał najprawdopodobniej miasto Gibeon ${ }^{86}$ położone około $5 \mathrm{~km}$ na północ od Jerozolimy, o czym świadczy kilka faktów:

- w Joz 10, 2 miasto to nazwane jest hammam lākāh - rezydencja królewska;

- wzniósł tam ołtarz (1 Sm 14, 33; 2 Sm 20, 8);

o samym Saulu oraz o jego synu Jonatanie. L. STACHOWIAK (Saul a Dawid na tle genezy monarchii izraelskiej, STV 26 (1988) nr 1, s. 26-27) pierwszą tradycję łączy z kołami prorockimi, druga jego zdaniem wykazuje silne wpływy deuteronomistyczne ukazujące Boga jako tego, który ustanawia władcę; przekaz trzeci ukazuje przejście władzy od urzędu sędziego do monarchii.

${ }^{81}$ N. NA'Aman, The Pre-Deuteronomistic Story of King Saul and Its Historical Significance, CBQ 54 (1992), s. 640-644. Podobnie uważa J. VAN SETERS (In Search of History. Historiography in the Ancient World and the Origins of Biblical History, New Haven 1983, s. 254-256), który jednak zaznacza, że czynnikiem decydującym o jego wyborze była odsiecz dla Jabesz-Gilead.

${ }^{82}$ J. WARzecha, Saul - wybrany, odrzucony i zniestawiony, CT 64 (1994) nr 4, s. 27.

${ }^{83}$ M. Grant, Dzieje dawnego Izraela..., dz. cyt., s. 93.

${ }^{84}$ J. BRIGHT, Historia ..., dz. cyt., s. 191

${ }^{85}$ D. Edelman, Saul Ben Kish in History and Tradition, [w:] The Origins of the Ancient Israelite States, ed. by V. Fritz, P. R. Davies, Sheffield 1996, s. 156 (Journal for the Study of the Old Testament. Supplement Series, 228). D. Edelman (Saul's Journey through Mt. Ephraim and Samuel's Ramah (1 Sam 9:4-5; 10:2-5), ZDPV 104 [1988], s. 57-58) uważa, że opis wędrówki Saula w poszukiwaniu oślic może opierać się na opowiadaniu o tym, w jaki sposób stawał się on królem zajmując krainy przez które wędrował: Szalisza (pogranicze pustyni pomiędzy Wadi Suwenit i Wadi s-Samiye lub Wadi Fasail), Szaalim (starożytne Szual w sąsiedztwie Ofra), Jimni (region Betel) i Zuf (obszar w okolicach Hirbet Raddana i Ras et-Tahume).

86 J. M. Miller (Geba/Gibeah of Beniamin, VT 25 [1975], s. 145-166) identyfikuje to miasto ze współczesnym Jeb'; uważa także, że biblijne Geba, Geba Beniamina, Gibea, Gibea Beniamina, Gibea Saulowe oraz Gibea-elohim są jedną i tą samą miejscowością. 
- jeszcze w czasie panowania Salomona Gibeon był ważnym sanktuarium religijnym ${ }^{87}$.

Według 1 Krn 8, 29-40; 9, 35-44 Saul wywodził się z klanu Nera powiązanego z Gibeonitami. Chociaż grób rodzinny znajdował się w niezidentyfikowanym Sela (2 Sm 21, 14; por. z Joz 18, 28), wszystko wskazuje na to, że rodzinny dom pierwszego króla Izraela znajdował się w okolicach $\mathrm{Gibeonu}^{88}$. Miasto to wiązane jest $\mathrm{z}$ tradycją i kultem kananejskim, dlatego według autorów biblijnych nie nadawał się on na króla Izraela; co gorsze, Saul jest ponadto jedyną postacią w genealogiach Księgi Kronik, u której brak powiązań z 12 synami Jakuba ${ }^{89}$.

Początków Gibeonitów szuka się między Edomitami, którzy opuścili swoją ojczyznę i wyruszyli na północ. Pod koniec XIII wieku przed Chr. część z nich mogła wkroczyć do Palestyny i utworzyć tam rodzaj enklawy. Gibeonici pozostali świadomi swej etnicznej odrębności. Wiele działań Saula wydaje się wskazywać na jego gibeonickie korzenie: podczas wyprawy przeciw Amalekitom oszczędził Kenitów (1 Sm 15, 6) z powodu ich powiązań z Edomem.

Odsiecz dla Jabesz-Gileadu mogła mieć podobne podłoże: zawierane były związki małżeńskie między Gibeonitami (określanymi jako „Beniaminici z Gibea” w Sdz 19-21) i mieszkańcami Jabesz (Sdz 21, 8-14); małżeństwa te mogły być oparte na poczuciu jedności etnicznej ${ }^{90}$.

W Gibeonie (identyfikowanym ze współczesnym Tell el-Ful) odkryto narożnik budowli obronnej o wymiarach ok. 11,6×17,8 m z murami kazamatowymi o grubości dochodzącej do ok. 4,5 m, które w niektórych miejscach przetrwały do wysokości ponad $2 \mathrm{~m}$. Jak się przypuszcza, mogła to być siedziba pierwszego króla izraelskiego. Pełny plan tej fortecy nie jest znany, poza tym, że miała ona wymiary $57 \times 62 \mathrm{~m}$; narożniki wzmocnione były basztami, których mury miały grubość ok. 1,5 m¹ . Być może właśnie tutaj „,król zasiadał na swym zwykłym miejscu na krześle pod ścianą" (1 Sm 20, 25).

Wojna z Filistynami prowadzona przez Saula miała charakter partyzantki, gdzie walczono z wrogiem urządzając zasadzki i przeprowadzając niespodziewane ataki na jego posterunki. W walce jednorazowo zaanga-

${ }^{87}$ J. Blenkinsopp (Did Saul Make Gibeon His Capital?, VT 24 [1974], s. 4-6) porównuje sytuację Gibeonu do Sychem w czasie krótkiego panowania Abimeleka.

${ }^{88}$ A. Demsky, Geba, Gibeah, and Gibeon - An Historico-Geographic Riddle, BASOR 212 (1973), s. 26-27. O powiązaniach Saula z Gibeonem i o znaczeniu samego miasta patrz także J. WARzecha (Dawny..., dz. cyt., s. 108-109).

${ }^{89}$ S. D. WALTERs, Saul of Gibeon, JSOT 52 (1991), s. 75.

${ }^{90}$ K. van der Toorn, Family Religion..., dz. cyt., s. 285-286.

${ }^{91}$ A. MAZAR, Jerusalem and Its Vicinity in Iron Age I, [w:] From Nomadism to Monarchy, ed. by I. Finkelstein and N. Na'aman, Jerusalem 1994, s. 77. 
żowana była raczej niewielka liczba wojowników: 1 Sm 13, 2 mówi o 2 tys. przebywających przy Saulu i tysiącu stacjonujących w innym miejscu pod dowództwem Jonatana, ale już 13, 15 wspomina tylko o 600. Sukcesem było zepchnięcie Filistynów z centralnych terenów Izraela. Zwycięstwa odnoszono walcząc w trudnym terenie górskim, natomiast słabo wyposażone oddziały izraelskie nie mogły wygrać bitwy na otwartej równinie, jak boleśnie się o tym przekonały w starciu pod wzgórzem Gilboa ${ }^{92}$.

W przerwach między walkami ze swoim głównym przeciwnikiem Saul starał się zbudować jakieś ekonomiczne podstawy swego państwa. Chodziło tu zwłaszcza o kontrolę nad lokalnymi szlakami handlowymi i znalezienie rynków zbytu dla zasobów i nadwyżek produkcyjnych własnego państwa. Było to przyczyną starć z innymi ludami, m.in. z Amalekitami (1 Sm 15, 5), gdy izraelskie wojsko niszczy wrogów „od Chawila w stronę Szur, leżącego naprzeciw Egiptu" "93. Podobną funkcję, oprócz wspomnianych wyżej więzów krwi, można przypisać odsieczy dla Jabesz-Gileadu (1 Sm 11,1-11), dzięki czemu miasto stało się terytorium wasalnym (2 Sm 2, 4-7 $)^{94}$.

Religia Saula - początki jahwizmu. Prowadząc walkę z najeźdźcami, Saul próbował jednocześnie podbudować swą władzę ideologicznie, wprowadzając kult Boga Jahwe, który prawdopodobnie był pierwotnie bóstwem jego rodu. Religia państwowa narodziła się w armii. W starożytności wojna nie była świeckim zajęciem - zwycięstwo zależało bardziej od bogów niż od waleczności człowieka; na swoje wyprawy wojenne Saul nie wyruszał bez kapłanów. Nawet broń wojowników była poświęcana (1 Sm 21, 5-6; $2 \mathrm{Sm}$ 11, 11). Żołnierze mieli status „ludu Jahwe” (2 Sm 1, 12) i prowadzili „wojny Jahwe” (1 Sm 18, 17; 25, 28), a zwyciężając poświęcali swych wrogów Bogu (1 Sm 15, 3. 8. 33). Dopiero później kult Jahwe rozwinął się wśród reszty ludu ${ }^{95}$. Jednak z pewnością nie był to kult jednego bóstwa, tak jak przedstawia to Biblia. Można tu szukać początków monoteizmu

92 A. Lemaire, Zjednoczone królestwo: Saul, Dawid i Salomon, [w:] Starożytny Izrael: od czasów Abrahama do zburzenia Jerozolimy przez Rzymian, przeł. W. Chrostowski, Warszawa 1994, s. 138.

${ }^{93}$ D. Edelman (Saul's Battle against Amaleq (1 Sam 15), JSOT 35 [1986], s. 71-84) uważa, że przy granicy terytorium Efraima istniała enklawa zamieszkiwana przez Amalekitów - rajd z tej strony był bardziej niebezpieczny niż wypad z Seiru przeciwko Judzie, która najprawdopodobniej nie podlegała jeszcze Saulowi.

${ }^{94}$ Politykę „ekonomiczną” Saula podkreśla I. FinKelstein (Arabian Trade and SocioPolitical Conditions in the Negev in the Twelfth-Eleventh Centuries B. C. E., JNES 47 [1988], s. 251). Natomiast D. Edelman (Saul's Rescue of Jabesh-Gilead (1 Sam 11, 1-11): Sorting Story from History, ZAW 96 [1984], s. 209) uważa, że opowiadanie o odsieczy dla Jabesz-Gilead ma przede wszystkim ukazać charyzmę zwycięskiego króla i opiera się na autentycznym raporcie z pola bitwy lub jakiegoś rodzaju roczniku królewskim.

${ }^{95}$ K. van der Toorn, Saul and the Rise of Israelite State Religion, VT 43 (1993), s. 528. 
w Izraelu, ale był to dopiero początek długotrwałego procesu, którego ukoronowaniem była reforma Jozjasza z 622 roku przed Chr.

Przyjmując, że Saul wywodził się z Gibeonitów, a ci pochodzą z Transjordanii, wydaje się bardzo prawdopodobne, że właśnie tutaj należy szukać początków „oficjalnego” kultu Jahwe-Ela wśród Izraelitów. Pogląd ten wydaje się potwierdzać lista topograficzna Ramzesa III na ścianie świątyni w Aamara w Sudanie, która jest odpisem listy Amenhotepa III z Soleh (także

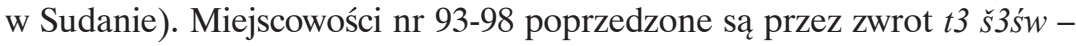
kraj Szasu. Podobne nazwy miejscowe pojawiają się w listach Totmesa III w Karnaku i Ramzesa III w Medinet Habu. Szczególnie interesująca jest nazwa regionu $t 3 s 3 s s w$, ya-h-wa (w liście Ramzesa III w formie $y i-h a$ ). Jak się wydaje z kontekstu listy, chodzi tu o miejsce położone gdzieś w Transjordanii - wskazuje tu na Edom, terytorium Kenitów, Madianitów lub Synaj ${ }^{96}$.

Często odróżnia się religię promowaną przez państwo od religii „popularnej" (zalicza się do niej m.in. rytuały związane z płodnością, porodem oraz ryty związane z ogniskiem domowym, prywatne modlitwy, praktyki pogrzebowe z ofiarami dla zmarłych, pielgrzymki do lokalnych sanktuariów itp. $\left.{ }^{97}\right)$. Należy tu jednak zachować dużą ostrożność - autorzy biblijni dostrzegali istnienie innych wspólnot religijnych, ale ich spojrzenie na religię inną od jahwistycznej jest zafałszowane - literaci z kręgu elity społecznej mogli świadomie błędnie przedstawiać wierzenia innych klas i grup ${ }^{98}$.

Upadek Saula. W Biblii wydarzenie to przedstawione jest z teologicznego punktu widzenia: ponieważ władca okazał nieposłuszeństwo woli Jahwe przekazanej mu przez Samuela i nie dopełnił krwawego $h$ 'érem nałożonego na Amalekitów (1 Sm 15, 7-26), musiał odejść. Dużym wykroczeniem było także złożenie ofiary przed bitwą, co było zastrzeżone tylko dla kapłana ${ }^{99}$. Było to świętokradztwo. Próbowano interpretować, że Saul złożył ofiarę składaną zazwyczaj w czasie pokoju (tzw. haššélāmîm), co odebrano jako próbę uniknięcia walki i w tym sensie akcja króla została zidentyfikowana

${ }_{96}$ M. C. Astour, Yahweh in Egyptian Topographic Lists, [w:] Festschrift Elmar Edel, 12. März 1979, hrsg. von M. Görg und E. Pusch, Bamberg 1979, s. 17-21. P. M. M. DaviaU i P. E. Dion (El, the God of Ammonites? The Alef-Crowned Head from Tell Jawa, Jordan, ZDPV 110 [1994], s. 158-162) uważają, że znaleziona w 1989 roku w Tell Jawa ukoronowana głowa bóstwa należy do Ela, bóstwa Ammonitów. Hipotezę tę opierają na podobieństwie znaleziska z wyobrażeniami znanymi z Ugarit.

${ }^{97}$ W. G. Dever, "Will the Real Israel Please Stand Up?". Part II: Archeology and the Religious of Ancient Israel, BASOR 298 (1995), s. 53.

98 J. Berlinerblau, The "Popular Religion" Paradigm in Old Testament Research: A Sociological Critique, JSOT 60 (1993), s. 13.

${ }^{99} \mathrm{~S}$. YonIcK, Rejection of Saul as King of Israel according to 1 Sam 15: Stylistic Study in Theology, Jerusalem 1970, s. 58-59. 
jako głupota i sprzeniewierzenie się woli Boga ${ }^{100}$. Wydaje się jednak, że istnieje jeszcze inne wytłumaczenie narastającego konfliktu między starym Samuelem i Saulem ${ }^{101}$. Pierwszy z nich namaszczając króla zapewne zastrzegł sobie władzę zwierzchnią nad przywódcą wojskowym, który w jego imieniu miał prowadzić Izraelitów do walki - dlatego m.in. nosił tytuł $n \bar{a} g \hat{\imath} d$, a nie melek. Sprawy cywilne i religijne zapewne nie podlegały jego kompetencjom. Stąd złożenie ofiary mogło zostać odebrane jako uzurpacja władzy przynależnej Samuelowi.

Interesujące jest to, że pierwszych władców Izraela określano mianem nāgîd, a nie stosowanym na całym Bliskim Wschodzie melek. Określenie nāgîd tłumaczy się jako „ten, który jest z przodu”, „przywódca ludu” i wywodzi od nōqèd oznaczającego pasterza. Stosowane było dla władcy wybranego przez Jahwe - np. Saula (1 Sm 9, 16; 10, 1), Dawida (2 Sm 5, 2; 7, 8); natomiast Salomon jest już nie tylko nāgîd, ale i melek $(1 \mathrm{Krl} 14,7)^{102}$. Prawdopodobna wydaje się więc hipoteza widząca w dwóch pierwszych nie królów, ale swego rodzaju przywódców wyznaczonych przez Boga (wyjątkiem byłyby tutaj powołania Salomona przez Dawida w 1 Krl 1, 35 oraz Abiasza przez Roboama w 2 Krn 11, 22); formułę religijną przyjęto dla celów politycznych ${ }^{103}$. Nâgî̀d oznaczałby wtedy wybieralnego dowódcę wojskowego, następcę władcy i dyskusyjne pozostaje jego pierwotne znaczenie $^{104}$. Stopniowa ewolucja roli przywódcy dała drogę do monarchii. Później określenie to stało się jednym z tytułów przysługujących monarsze ${ }^{105}$.

Historia nie była łaskawa dla pierwszego władcy Izraela. Saul, nie należąc do dynastii Dawida, musiał zostać zapomniany do takiego stopnia, jak to tylko możliwe. Ale sam fakt, że przetrwała pamięć o nim i o jego czynach, świadczy, że uważano go za postać wybitną ${ }^{106}$. Jego kariera zakończyła się

${ }^{100}$ A. Popović, Saul's Fault in 1 Sam 13, 7b-15a- Why Has the First Israelite King Fallen?, „Antonianum” 68 (1993), s. 165-168.

${ }^{101}$ J. VAn Seters (In Search..., dz. cyt., s. 257) stwierdza, że motyw oczekiwania na Saula i złożenia ofiary przez Saula nie jest oryginalną częścią opowiadania. Jest to wstawka redakcyjna wiążąca opowiadania o wyborze Saula i jego odrzuceniu.

${ }^{102}$ S. Yonick (Rejection..., dz. cyt., s. 21-23) uważa, że oba te określenia mają podobne znaczenie. Stąd król - przywódca znany był także jako pasterz. J. S. ACKERMAN (Prophecy..., art. cyt., s. 7) uważa, że tytuł nāgîd noszony był przez przedmonarchicznego urzędnika plemion północnych.

${ }^{103}$ W. Richter, Die nāgīd-Formel. Ein Beitrag zur Erhellung des nāgīd-Problems, BZ 9 (1965), s. 71-84.

${ }^{104}$ T. N. D. Mettinger, King and Messiah. The Civil and Sacral Legitimation of the Israelite Kings, Lund 1976, s. 152-184.

105 J. W. Flanagan, Chiefs..., art. cyt.., s. 67-68. E. Lipiński, Nāgīd, der Kronprinz, VT 24 (1974), s. 497-499.

${ }^{106}$ G. W. Ahlström, The History of Ancient Palestine..., dz. cyt., s. 452. L. StachowiaK (Saul..., art. cyt., s. 16-17) wśród kręgów niechętnych Saulowi wskazuje na koła kapłańskie wokół 
dramatycznie: wdając się w bitwę na równinie (być może wciągnięty w zasadzkę), do której jego wojska nie były przygotowane, poległ, a niedługo później dynastia Saulidów straciła tron na rzecz nowego władcy Dawida.

Powstało państwo, jedno z najbardziej znanych w historii starożytnej, które dzięki swej kulturze i religii przetrwało na kartach ksiąg biblijnych aż do czasów współczesnych. Mało kto jednak zastanawia się, kim byli ludzie, którzy mieli decydujący wpływ na jego powstanie. Sędziowie, Saul czy Dawid wydają się nam postaciami niemal abstrakcyjnymi, a przecież oni także byli ludźmi mającymi swoje zmartwienia i radości. Wpływ, jaki wywierali na swoich współczesnych, zadecydował, że Izrael nie tylko nie rozpłynął się w masie innych ludów, ale potrafił stworzyć własne państwo. W świadomości Żydów przetrwało ono tysiąclecia.

Czynnikiem decydującym o powstawaniu państwa było niewątpliwie ciągłe zagrożenie ze strony ludów sąsiednich. Następowały jednak także duże zmiany w łonie samego Izraela. Osiadły tryb życia i ciągłe walki spowodowały, że wykształciła się elita ziemiańsko-wojskowa. Chcąc utrzymać swoją pozycję oraz zabezpieczyć się ze strony warstw niższych, popierały one silną władzę centralną. Na nich opierał się Saul, a później także Dawid.

Królowie Izraela znani są stosunkowo dobrze dzięki opisom biblijnym, natomiast ich poprzednicy - sędziowie - niemal nikną w mroku dziejów. Nic więc dziwnego, że pojawiają się liczne głosy zaprzeczające ich historyczności. Jednak rozważania zawarte w niniejszym artykule wskazują, że istnieją liczne dane, które pozwalają umieścić te postacie w kontekście nie tylko dziejów samego Izraela, ale także całego starożytnego Bliskiego Wschodu; Izraelici korzystali z dorobku wielu ludów już od najwcześniejszych swoich dziejów. Interesująca jest zwłaszcza kwestia sprawowania funkcji religijnych przez ludzi posiadających także władzę świecką. Czynili tak sędziowie, ich śladem poszli także późniejsi władcy. To właśnie na tej płaszczyźnie należy rozpatrywać konflikt pomiędzy Samuelem i Saulem, który doprowadził w efekcie do odsunięcia starego sędziego.

Religijne wsparcie dla władzy było stosunkowo najprostszym, ale przy tym i najskuteczniejszym sposobem wywierania wpływu na ludzi podległych. Była to praktyka stosowana w całym świecie starożytnym. Sędziowie byli czcicielami różnych bogów, najczęściej wymieniani są Baal i El, oraz licznych bóstw opiekujących się ich rodami. Tylko nielicznych można powiązać z Jahwe. Dopiero dzięki poparciu królów powstała religia całego narodu

Dawida (1 Sm 13, 7-15). Jak pisze J. WARZEChA (Dawny..., dz. cyt., s. 112): „Wydaje się, iż pierwszy król w Izraelu zasługuje na więcej uznania i sympatii, niż mu to okazali autorzy biblijni”. 
- to Saul zadecydował, że religią państwową stał się jahwizm. Krok ten miał - jak się okazało - decydujące znaczenie dla całej historii Izraela oraz kolosalne znaczenie dla dziejów całej ludzkości.

Lublin

FABIAN TRYL

\section{Summary}

\section{From Othniel to Saul. The origins of Israel's state}

Period after Joshua's death was very important in history of Israel. Unorganised tribes were been under influences of better-developed Canaanites and only begun to create more monolith society. Additional factors have been dangerous from outside and numerous invasions of enemies so sometimes Israel was a subordinate foreigner ruler.

Overcoming particularisms and trying to set against this situations Israelites inducted kind of rulers governing of federations of few tribes, who Bible call "the Judges". Etymology of this term and similar examples from another regions of ancient Near East sign its sacro-political character. Has been trust that appointed they God alone in answer of petitions of Israelites. Book of Judges mentions row of names but not much we know about these persons. However seem that much of they it's possible to relate with priestly tribe of Levites.

Situation becomes especially dangerous when Israelites have begun war with better-organised and armed Philistines. It was time of last and greatest judge, Samuel, who appointed first king of united state Israelites, Saul. He didn't rule long and post successfully fights with Philistines was killed in battle. However earlier was happened something what caused Saul with Samuel and Yahweh "rejected" king. As his successor is induct David, who however got power just after Saul's death.

On time of first king of Israel is date beginning of Yahwism as a state-religion. It didn't mean Israelites were become monotheists but it was first step of this process where faith of Yahweh been one of most important factors keeping the sense unity among the Israelites.

Negative image of Saul in the Bible most probably created writers connected with later kings from David's dynasty. 